\title{
Assessment of Anthropogenic Impact versus Climate Change on the Succession of the Diatom Community in Lugu Lake (Yunnan-Guizhou Plateau, China) Using the Sedimentary Record of Geochemical Elements
}

\author{
Yi Liu ${ }^{1,+}$, Chuanhong Chen ${ }^{2, \dagger}$ and Shao Yang ${ }^{1, *}$ \\ 1 School of Life Sciences, Central China Normal University, Luoyu Road, Wuhan 430079, China; \\ yiliu0713@sina.com \\ 2 School of Chemical Biology and Materials science, East China University of Technology, Nanchang 330013, \\ China; cchuanhong@163.com \\ * Correspondence: yangshao@mail.ccnu.edu.cn; Tel.: +86-027-67867221 \\ $\dagger$ These authors contributed equally to this work.
}

Received: 12 December 2018; Accepted: 27 March 2019; Published: 29 March 2019

check for updates

\begin{abstract}
The lake ecosystems on the Yunnan-Guizhou Plateau in China have degraded in recent decades under the effects of anthropogenic activities and climate change. The human impact on the oligotrophic Lugu Lake aquatic ecosystem was evaluated using the sediment records of metals, nitrogen isotopes $\left(\delta^{15} \mathrm{~N}\right)$ and magnetic susceptibility over the past 200 years. Three periods were identified based on the trace metal and $\delta^{15} \mathrm{~N}$ records. During the first stage (1816-1976 AD), the concentrations of metals, $\delta^{15} \mathrm{~N}$ and magnetic susceptibility were low with small variations. The anthropogenic contributions to the inputs were also small, except for Ni, reflecting minor human activities in the watershed, and no significant change was observed in the sediment record of the diatom assemblage. During the second stage (1976-2001 AD), the concentrations of $\mathrm{Zn}$ and $\delta^{15} \mathrm{~N}$ increased, as well as the anthropogenic contribution of Zn. However, no significant change was detected in the anthropogenic sources of the other metals. These results reflect the low-level use of chemical fertilizers. The major shift in the sediment diatom assemblage during this stage was mainly attributed to regional climate change. During the third stage (2001-2010 AD), the concentrations of the sedimentary metals ( $\mathrm{Ni}, \mathrm{Cr}, \mathrm{Mn}, \mathrm{Cu}, \mathrm{Hg}$ and $\mathrm{Al}$ ) increased rapidly, with the exception of As and $\mathrm{Zn}$, and a similar increasing trend was observed in the changes by anthropogenic sources of $\mathrm{Ni}, \mathrm{Cr}$, $\mathrm{Mn}$ and $\mathrm{Cu}$. RDA (Redundancy Analysis) and variance partitioning analysis showed that the human impact and climate proxies independently explained $31.59 \%$ and $4.26 \%$ of the change of diatom community, respectively, and the interaction between climate change and human impact accounted for $18.61 \%$ of the change of diatom community. Tourism-dominated human activities, which were reflected in the metals profiles, facilitated the dominance of eutrophic species and reduced that of oligotrophic species. The development of tourism was likely the main driving force for the succession of diatom assemblages in the third stage. In summary, the anthropogenic input of trace metals in Lugu Lake is still at a low level. However, the significant growth trend in metals over the past decade is significantly related to the change in the lake ecosystem. Therefore, the effects of human activities, especially tourism, on the watershed should be controlled for the protection of the oligotrophic Lugu Lake.
\end{abstract}

Keywords: Lugu Lake; sediment record; anthropogenic impact; climate change; aquatic ecosystem 


\section{Introduction}

The ecological degradation driven by climate change and human impact has been a hot topic in environmental science in recent decades [1]. A number of reports have demonstrated the evidence of the impact of climate change or human activities on aquatic ecosystems [1,2]. Since most of the aquatic ecosystems have been affected by both the climate change and human impact simultaneously, it is necessary to identify which stress is the main problem for specific ecosystems during lake management. However, literature about the quantitative assessment of the impacts of climate change and human activities on aquatic ecosystems is scarce.

Lakes in China are mainly distributed in five regions. Among these regions, the southwestern lake region is located on the Yunnan-Guizhou Plateau, adjacent to the Qinghai-Tibet Plateau, and hosts diverse aquatic ecosystems and abundant biodiversity [3]. The geographical characteristics of this region-high elevation, low latitude, and within a plateau monsoon climate-make it an interesting area to study the response of the ecosystems to climate change [4,5]. In addition, the lakes in this region are mostly closed or semi-closed with long retention times; therefore, the lakes easily become eutrophic due to the accumulation of nutrients and are difficult to rehabilitate. As a result, the control of the anthropogenic impact in the watershed is vital for the protection of the lake ecosystems in this region $[4,6]$.

Lugu Lake, a deep alpine lake in the southwestern lake region, is one of the cleanest oligotrophic lakes in China. It has become a famous resort over the past decade due to its unique biodiversity, beautiful scenery and the mysterious matriarchal indigenous culture. Therefore, the control of the aquatic ecosystem and water quality of Lugu Lake is of great interest to the local government due to the increasing pressure of tourism. It is also an interesting place to study the impact of climate change and human disturbance on an aquatic ecosystem because of its geographic position, low population density and low industrial development level in the Lugu Lake Basin [7]. For example, Wang et al. [5] investigated the history of regional climate change from $24,500 \mathrm{cal}$. year BP based on a sedimentary diatom record. Chen et al. [4] reported on the response of a diatom community in Lugu Lake to climate change over the past century using paleolimnological analysis. They suggested that regional warming was the main driving force behind recent changes to the diatom assemblage in the lake, while nutrients may also have had an impact on the diatom changes over the past 10 years. Evidence of anthropogenic disturbance in the Lugu Lake Basin over the past centuries has also been reported. Zhang et al. [8] found that land-use change in the Lugu Lake catchment, including deforestation, resulted in a minor increase in allogenic clastic mineral inputs and a recent period of expanding tourism may have resulted in nutrient enrichment of the lake. Lin et al. [9] analyzed the sediment record of trace metals at Lugu Lake and suggested that the recent increase in the sediment trace metal concentrations may be related to the enhanced emission of non-ferrous metals on the Yunnan-Guizhou Plateau. The recent increasing trend in anthropogenic impacts in the catchment has raised concerns. However, the contributions of climate change and the local anthropogenic disturbance to the aquatic ecosystem of Lugu Lake have not been evaluated quantitatively, which limits the development of strategies for lake management.

The anthropogenic impact on aquatic ecosystems has been previously assessed using paleolimnological methods. Sediment proxies, for example, $\mathrm{C}$ and $\mathrm{N}$ isotopes, organic matter and geochemical element content, were used to characterize the anthropogenic disturbance caused by, for example, agriculture, industry and tourism $[10,11]$. The sediment records of the residues of aquatic organisms, such as sporopollen, chironomid, diatom and ancient sediment DNA, were used to reconstruct the history of aquatic ecosystems $[10,12,13]$. For example, pollen and isotope data were used to represent ecological changes and anthropogenic disturbance, respectively, in a study of the response of aquatic ecosystems in White Lake (New Jersey, USA) to industrial pollutants and the implementation of environmental regulations [10]. In another study, analyses of diatoms and geochemical elements $(\mathrm{Pb}, \mathrm{Hg}, \mathrm{Cd}, \mathrm{Bi}, \mathrm{Co}, \mathrm{Zn}, \mathrm{Cu}, \mathrm{Ni}$, and $\mathrm{Mn}$ ) preserved in the sediment of $\mathrm{Lac}$ Dauriat (subarctic Quebec) were performed to evaluate the impacts of nearby mining activity and the expansion of the town of Schefferville on the water quality of the lake [12]. Diatom assemblages, 
sedimentation rates, organic and trace metal accumulation rates and GIS-reconstructed land-use stresses were also analyzed in Lake Superior (Michigan, USA and Ontario, Canada) to evaluate the lake history and the impacts of human activities [11].

Tourism and agriculture are the main anthropogenic activities in the catchment of Lugu Lake. The geochemical elements in the sediment can reflect human activities such as mining, coal and oil combustion, waste water discharge and other disturbances [14]. Phytoplankton are the important primary producers in aquatic ecosystems and are generally sensitive to environmental changes [15]. As the main component of phytoplankton in Lugu Lake, the diatom record in the sediment is a suitable proxy to reflect changes in the aquatic ecosystem [8].

This study analyzed the changes in metals and $\delta^{15} \mathrm{~N}$ in a high-resolution dated sediment core from Lugu Lake spanning the past century, and the results were compared with the diatom record in the sediment. The aims of this study were: (1) to evaluate the historic changes in the anthropogenic impacts using geochemical records (metals and $\delta^{15} \mathrm{~N}$ ) obtained from the sediment, and (2) to quantitatively assess the contributions of the local anthropogenic impact and climate change on the succession of the diatom communities in Lugu Lake. This report identified the main driving force for the change of the lake ecosystem, which provides important information for the ecosystem protection and management of Lugu Lake, as well as for the lakes in the southwestern lake region of China.

\section{Materials and Methods}

\subsection{Study Site}

Lugu Lake $\left(27^{\circ} 41^{\prime}-27^{\circ} 45^{\prime} \mathrm{N}, 100^{\circ} 45^{\prime}-100^{\circ} 50^{\prime} \mathrm{E}, 2690 \mathrm{~m}\right.$ asl) lies on the boundary between Yunnan and Sichuan provinces in southwest China on the southeast margin of the Tibetan Plateau (Figure 1). The surface area of Lugu Lake is approximately $49 \mathrm{~km}^{2}$ and the catchment area is approximately $171 \mathrm{~km}^{2}$. As a semi-closed, deep tectonic lake, it has a maximum depth of $93.5 \mathrm{~m}$ and a mean depth of $40.3 \mathrm{~m}$. Lugu Lake is mainly recharged by surface runoff and precipitation with a recharge coefficient of 3.54. There are two main inflow rivers, the Shankua in the east and the Sanjiacun in the south. The Caohai wetland is the only outlet for the lake water [16].

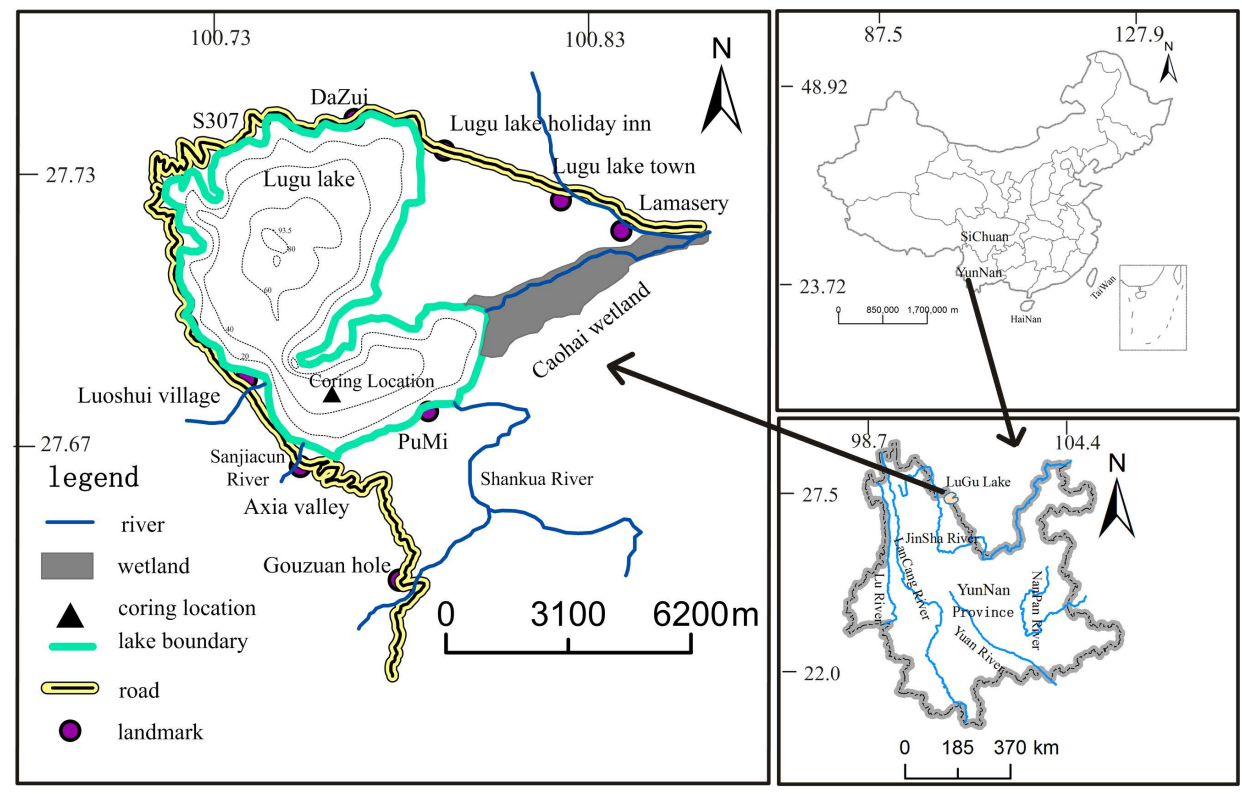

Figure 1. Coring site and map of Lugu Lake.

The climate of the Lugu Lake region has distinct dry-wet seasons with a total annual precipitation of $\sim 940 \mathrm{~mm}$. The precipitation associated with the southwest monsoon during the wet season from May to September accounts for more than $80 \%$ of the annual total [5]. The mean annual temperature is 
$12.7^{\circ} \mathrm{C}$ with a maximum monthly mean of $19.1^{\circ} \mathrm{C}$ in July and a minimum of $4.2^{\circ} \mathrm{C}$ in January. Forest is the dominant land-use type $(85.9 \%)$ in the catchment, followed by agricultural land $(8.44 \%)$ and grass/pastures (5.47\%) [17].

\subsection{Field Sampling}

A $25.5 \mathrm{~cm}$-long core was obtained from Lugu Lake using a gravity corer at a water depth of $41.1 \mathrm{~m}$ (Figure 1). The sampling site was located in the deepest region of southern part of Lugu Lake, between the main resort village of Luoshui and the farmland region to the east, where the main region affected by human activities in the catchment is located. The sediment core was sectioned into $0.5 \mathrm{~cm}$ contiguous intervals on site, sealed in plastic bags, and stored in a freezer at $-20{ }^{\circ} \mathrm{C}$. The samples for geochemical elemental analysis were freeze-dried in the laboratory before analysis.

\subsection{Laboratory Analyses}

The sediment dating results were described in a previous paper by our team [4]. Chronology of the core was established by the decay profile of unsupported ${ }^{210} \mathrm{~Pb}$ activity and the constant rate of supply (CRS) model. Sediment accumulation rate (SAR) ranged from 0.057 to $0.169 \mathrm{~g} \mathrm{~cm}^{-2}$ year $^{-1}$. The results suggest that the sediment core in this study spanned approximately 200 years and that the age of the bottom of the core can be extrapolated back to 1816 AD.

All the subsamples were digested using the Four-Acid $\left(\mathrm{HF}-\mathrm{HClO}_{4}-\mathrm{HNO}_{3}-\mathrm{HCl}\right)$ method [18]. The $\mathrm{Pb}$ levels in the digestive solution were determined using graphite furnace atomic absorption spectrometry (Shimadzu, AA6300, Japan) and $\mathrm{Cr}, \mathrm{Cu}, \mathrm{Zn}, \mathrm{Mn}$, and Ni were analyzed using flame atomic absorption spectrometry (Shimadzu, AA6300, Japan) according to the method described in [19]. Al was analyzed using ICP-AES (VARIAN VISTA-MPX, USA). As and Hg were analyzed with an Atomic fluorescence spectrophotometer (Beijing Titan, AFS-820, China). Certified soil reference materials (GBW07408, certified by IGGE) were used as quality control. The nitrogen isotopic composition of the sediment was analyzed using an Isotope Mass Spectrometer (Isoprime100, Germany). The nitrogen isotope ratios are expressed in the delta notation $\left(\delta^{15} \mathrm{~N}\right)$ in per mil relative to the Vienna Pee Dee Belemnite (VPDB) standard and atmospheric nitrogen. The mass magnetic susceptibility was measured using an MS2 magnetic susceptibility meter (Bartington, England). The sediment diatom and climate data (after 1951) used in this paper have been previously reported by our laboratory [4].

\subsection{Geo-Accumulation Index and Enrichment Factor Calculation}

The geo-accumulation index (Igeo) and Enrichment factor (EF) were applied to evaluate the pollution intensity of each trace metal in the lake sediment, calculated according to Equations (1) and (2) [20,21]:

$$
\begin{aligned}
& \text { lgeo }=\log _{2}\left(\mathrm{M}_{\mathrm{S}} / 1.5 \mathrm{M}_{\mathrm{B}}\right) \\
& \mathrm{EF}=(\mathrm{M} / \mathrm{Al})_{\mathrm{S}} /(\mathrm{M} / \mathrm{Al})_{\mathrm{B}}
\end{aligned}
$$

where $\mathrm{M}_{\mathrm{S}}$ is the concentration of the trace metals analyzed in the sediment, $\mathrm{M}_{\mathrm{B}}$ refers to the baseline concentration in rarely disturbed deposits, $(\mathrm{M} / \mathrm{Al})_{\mathrm{S}}$ is ratio of detected elements to $\mathrm{Al}$ concentrations in the samples and $(\mathrm{M} / \mathrm{Al})_{\mathrm{B}}$ is that in the baseline. The metal concentration in the deeper part of the sediment profile can be used as a baseline concentration based on the assumption that anthropogenic activities were negligible in the past $[20,22]$. In this study, we selected the average metal concentrations within the depth range of $24.5-25.5 \mathrm{~cm}$ (i.e., pre-1840) as the baseline values.

\subsection{Statistical Analysis}

The geochemical elemental data were plotted using the C2 1.5 program [23]. The geochemical element-based zones were identified using the constrained incremental sum of squares (CONISS) facility in the TILIA and TILIAGRAPH computer programs. Multivariate analyses were employed to examine the relationships between the diatom communities. For multivariate analyses, only species 
with percent relative abundances of $\geq 1 \%$ in at least one sample were selected. All environmental variables (after 1951) were normalized using a $\log (x+1)$ transformation to minimize discrepancies between measurement units and to reduce the effect of extreme values [24]. Diatom data were square root transformed to stabilize variance, with rare species down-weighted. Detrended correspondence analysis (DCA) with detrending by segments was applied to the diatom percentage data to explore the temporal patterns of species changes. A DCA axis 1 gradient length of 1.53 SD was obtained, indicating that linear statistical methods [PCA (principal components analysis) and RDA (redundancy analysis)] were appropriate to explore the relationships between the diatom assemblages and the environmental variables [25]. Monte Carlo permutations were used to test for the significance of each environmental variable in the RDA, and only those variables with $p<0.05$ under 999 permutations were accepted for model selection [24]. Collinearity between environmental variables was identified using Variance Inflation factors (VIF) and variables with VIF $>20$ were deleted [25]. Forward selection was used to identify environmental variables in the minimum adequate model that exert significant influence on the biological data, with Akaike's Information Criterion (AIC) chosen as the selection criterion [26]. The method of variance partitioning was applied to analyze the independent and interactive role of the selected variables in affecting biological changes with the application of RDA [26]. All statistical analyses were performed in the R program (version 2.2.1) using the vegan package [27]. The descriptive statistics, the Pearson and Spearman correlations of the metals variables and the biological variations in diatoms were calculated using SPSS version 15.0.

\section{Results}

\subsection{Sediment Records of Geochemical Elements}

Profiles of the change in the metals, $\delta^{15} \mathrm{~N}$, and magnetic susceptibility in the Lugu Lake sediments are presented in Figure 2. Three zones were identified based on the sediment records of the metals and $\delta^{15} \mathrm{~N}$ using Constrained Cluster analysis (Figure 2). Zone I (25.25-12 1816-1976 AD): the concentrations of all the geochemical elements remained low with small variations. Magnetic susceptibility was also low, between seven to $10 \times 10^{-8} \mathrm{~m}^{3} / \mathrm{kg}$. Zone II (12-4.25 cm: 1976-2001 AD): $\mathrm{Pb}, \mathrm{Zn}$, and $\delta^{15} \mathrm{~N}$ concentrations showed a significant increase at the beginning and a decrease at the end of this period. Similar evidence with small variations was also found for Al. The magnetic susceptibility also exhibited a small increase up to $13.4 \times 10^{-8} \mathrm{~m}^{3} / \mathrm{kg}$. Zone III (4.25-0 cm: 2001-2010 AD): the Zn concentration remained stable, while As decreased and $\mathrm{Pb}$ increased slightly. The concentrations of all the other metals, magnetic susceptibility, and $\delta^{15} \mathrm{~N}$ showed a rapid increase. Among all the profiles, only arsenic differed and remained relatively stable over the past century but decreased after 2003. The stable isotopes of nitrogen $\left(\delta^{15} \mathrm{~N}\right)$ remained fairly constant and remained below $4 \%$ in most parts of the core, apart from two small peaks detected from the 1910s to the 1920s and the 1980s, and increased rapidly during the past three years of the record. 


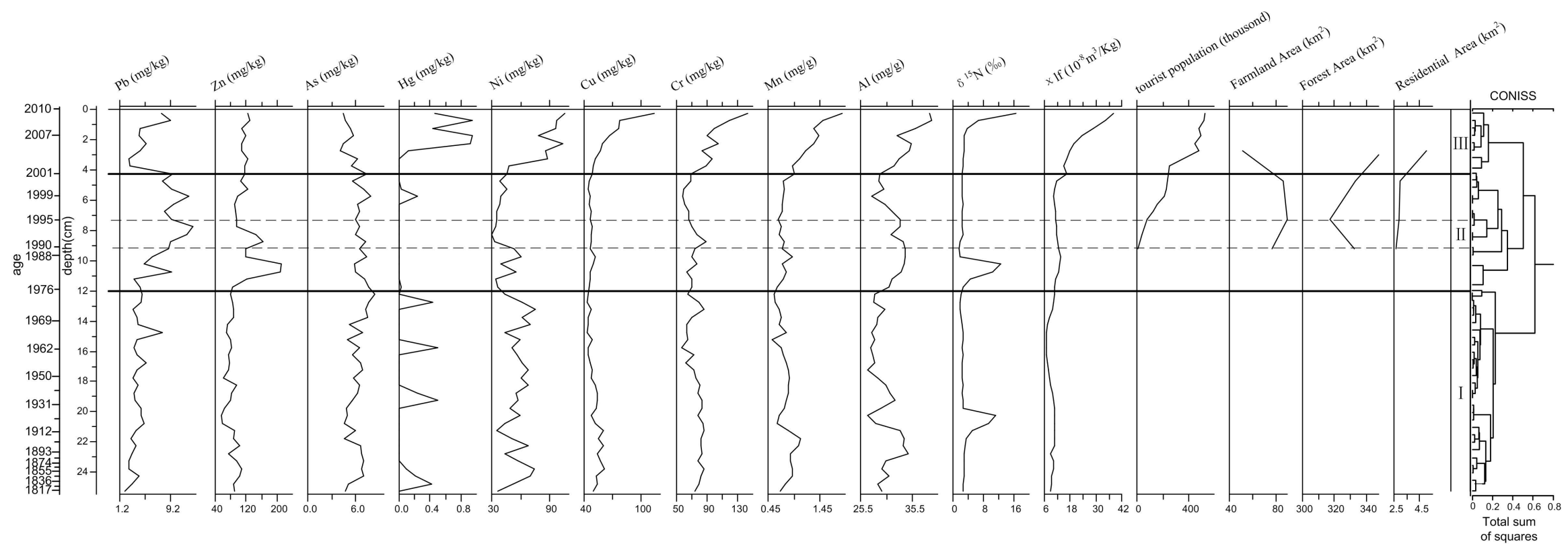

Figure 2. Vertical profiles of metals, nitrogen isotopes, and magnetic susceptibility in the Lugu Lake sediments and the tourist population in the watershed. On the right is the constrained incremental sum of squares (CONISS) based on elemental data. $\delta^{15} \mathrm{~N}$ (nitrogen isotope ratios), $\chi \mathrm{lf}$ (low frequency magnetic susceptibility). The tourist population, Farmland Area, Forest Area and Residential Area data (1989-2010 AD) were obtained from Don et al. [28] and Zhang et al. [8]. 


\subsection{Geo-Accumulation Index and Enrichment Factor}

The classification on the basis of the Igeo and EF values is listed in Table 1 [29]. The Igeo and EF profiles of the metals in the Lugu Lake sediment are presented in Figure 3, apart from the Igeo and EF of $\mathrm{Hg}$, which could not be detected because the baseline was below the detection limit. The Igeo indices of all metals were less than zero at the deepest end of the core, which indicates the pollution of all the metals were negligible 200 years ago. $\mathrm{Cu}, \mathrm{Cr}, \mathrm{As}, \mathrm{Mn}$ and $\mathrm{Zn}$ remained at an unpolluted to moderately polluted state throughout the sediment record. $\mathrm{Pb}$ and $\mathrm{Ni}$ increased to a level of moderately polluted at different times, as demonstrated by the Igeo profiles. All the metals except $\mathrm{Pb}$ remained at a no or minor enrichment state throughout the sediment record. The Igeo and EF results suggest that the pollution intensity of all metals was still at a low level. However, significant increases were observed since $2000 \mathrm{AD}$ in $\mathrm{Cu}, \mathrm{Cr}, \mathrm{Ni}$ and $\mathrm{Mn}$ (Figure 3), indicating a possible increase in anthropogenic activities from 2000 AD to 2010 AD.
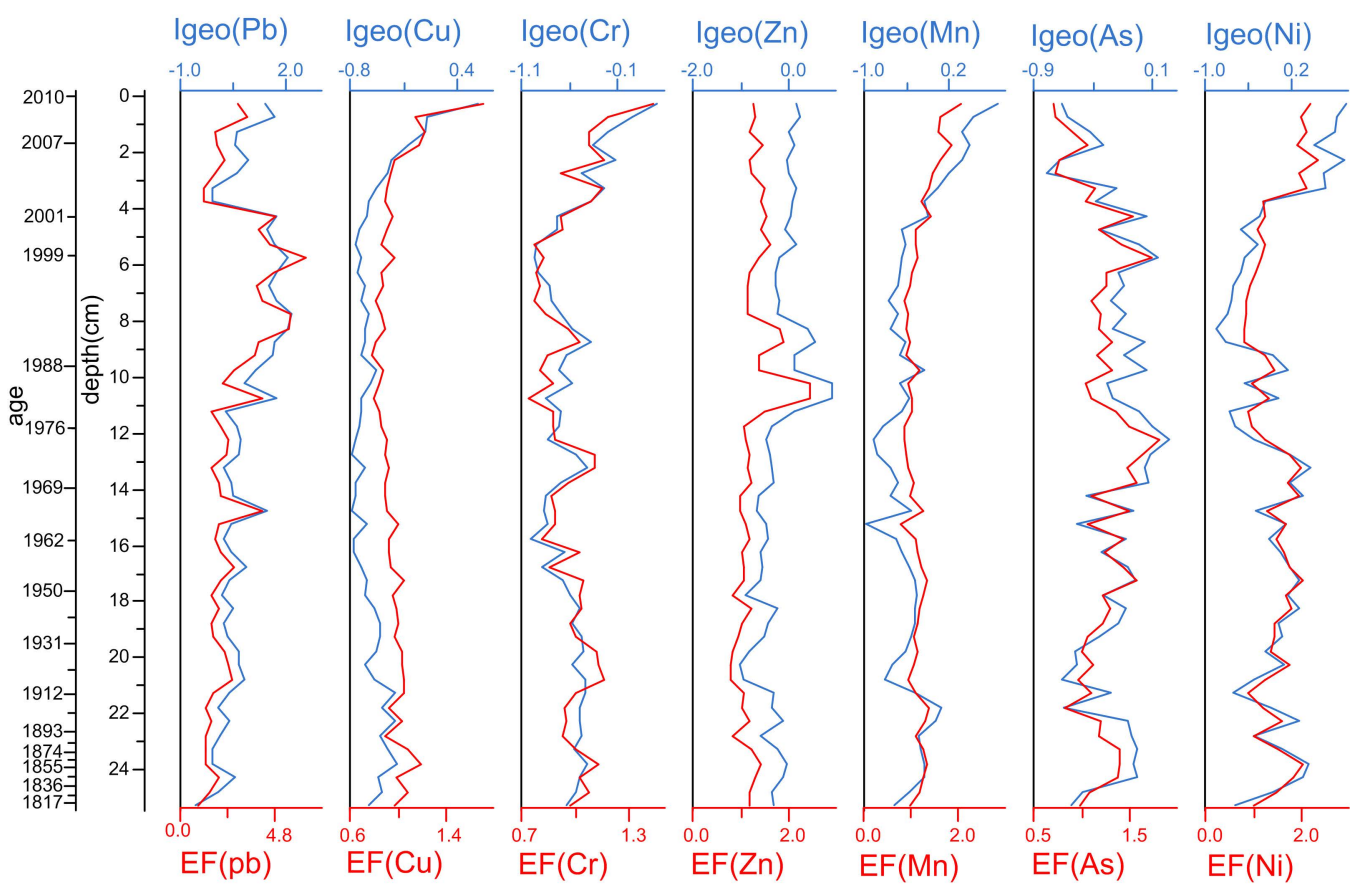

Figure 3. Geo-accumulation index (Igeo) and enrichment factor (EF) depth profiles of trace metals in the Lugu Lake sediment core. The blue and red lines represent Igeo and EF profiles respectively.

Table 1. Igeo and EF classification in relation to sediment quality $[20,29]$.

\begin{tabular}{cccc}
\hline Igeo & Sediment Quality & EF & Sediment Quality \\
\hline$\leq 0$ & Unpolluted & $<1$ & No enrichment \\
$0-1$ & Unpolluted to moderately polluted & $1-3$ & Minor enrichment \\
$1-2$ & Moderately polluted & $3-5$ & Moderate enrichment \\
$2-3$ & Moderately to highly polluted & $5-10$ & Moderately severe enrichment \\
$3-4$ & Highly polluted & $10-25$ & Severe enrichment \\
$4-5$ & Highly to very highly polluted & $>25$ & Extremely severe enrichment \\
$>5$ & Very highly polluted & & \\
\hline
\end{tabular}

\section{Discussion}

\subsection{History of Changes in the Anthropogenic Activities in the Lugu Lake Catchment}

The metals in aquatic sediments are derived from atmospheric deposition, weathering of bedrock and soils, and the afflux of domestic wastewater and runoff from agricultural land within the catchment, and can therefore be used as proxies for the assessment of anthropogenic activities [30]. As a result, 
distinguishing the contributions of different sources to the sediment record of the metals is necessary for the evaluation of the local anthropogenic impact.

Metals can be transported and adsorbed at fine particles over long distances through the atmosphere [31]. It is possible to identify the source of the metals by comparing the sediment records with the history of change in atmospheric metals in China. Tian et al. [31] reported anthropogenic atmospheric emissions of typical metals in China for the period of 1949-2012 (Appendix Figure A1). The sediment profile of $\mathrm{Pb}$ is similar to its atmospheric emission history, which increased in the 1970s and sharply decreased at the end of the last century due to the ban on leaded gasoline. It began to increase again since 2000 due to the increase of ferrous and nonferrous metal smelting. This evidence suggests that long distance transport is the main source of $\mathrm{Pb}$ in Lugu Lake and not anthropogenic activities within the lake catchment. Therefore, $\mathrm{Pb}$ was excluded from the following analysis. However, distinct differences were observed in the atmospheric emission histories and the sediment records of $\mathrm{Zn}, \mathrm{Ni}, \mathrm{Cr}, \mathrm{Mn}, \mathrm{As}, \mathrm{Cu}$ and $\mathrm{Hg}$. The atmospheric emissions of $\mathrm{Cu}, \mathrm{Zn}, \mathrm{Hg}, \mathrm{Ni}, \mathrm{Cr}, \mathrm{Mn}$ and $\mathrm{As}$ began to increase rapidly in the 1970s [31], whereas the sediment concentrations of $\mathrm{Cu}, \mathrm{Hg}, \mathrm{Ni}, \mathrm{Cr}$ and Mn began to increase from 2000. The concentration of $\mathrm{Zn}$ has remained unchanged since the 1990s. The concentration of As remained at a constant level with small variations over the past century and even declined after 2007. The above differences between the atmospheric emission histories and the sediment records suggest that sediment trace metals $\mathrm{Zn}, \mathrm{Ni}, \mathrm{Cr}, \mathrm{Mn}, \mathrm{As}, \mathrm{Cu}$ and $\mathrm{Hg}$ originated mainly from local natural and anthropogenic sources and can be used for the assessment of human activities in the Lugu Lake catchment.

The contributions of the natural and anthropogenic sources to the sediment trace metals can be calculated according to Zeng et al. [30]. Taking the Al concentration as an indicator of the background metal values supplied by weathering, the natural and anthropogenic component of the trace metals can be calculated as: $\mathrm{M}_{\text {natural }}=\mathrm{Al}_{\text {sample }} \times \mathrm{M}_{\text {background }} / \mathrm{Al}_{\text {background }}, \mathrm{M}_{\text {anthropogenic }}=\mathrm{M}_{\text {sample }}-\mathrm{M}_{\text {natural }}$. Where $M_{\text {anthropogenic, }} M_{\text {natural }}, M_{\text {sample }}$ and $M_{\text {background }}$ are the anthropogenic, natural, total and background concentrations of a considered metal, and $\mathrm{Al}_{\text {sample }}$ and $\mathrm{Al}_{\text {background }}$ are the total and background concentrations of reference element $\mathrm{Al}$, respectively. The natural and anthropogenic contributions can then be calculated as: $[M]_{\text {natural contribution }}=\mathrm{M}_{\text {natural }} / \mathrm{M}_{\text {sample }} \times 100 \%$, $[\mathrm{M}]_{\text {anthropogenic contribution }}=\mathrm{M}_{\text {anthropogenic }} / \mathrm{M}_{\text {sample }} \times 100 \%$. This method takes the soil loss of each element as the natural contribution, attributes the total sediment $\mathrm{Al}$ to the natural source of soil loss, and then calculates the soil loss of other elements using the natural source of $\mathrm{Al}$ as a reference. However, the $\mathrm{Al}$ element in the sediment may not be completely attributed to soil loss and may also originate from anthropogenic input. In addition, the loss rates from soil of all the elements may not be identical; therefore, the results obtained by this method were only an estimate of the natural and anthropogenic contributions [32].

The anthropogenic and natural sources of several trace metals that are most relevant to human activities are shown in Figure 4, excluding $\mathrm{Hg}$ and As. The contributions of the different $\mathrm{Hg}$ sources cannot be calculated because most of the values were below the detection limit. Furthermore, most of the Igeo values for As in the whole sediment core were below zero, indicating that there has been no significant input of As into Lugu Lake, especially in recent decades.

Three zones were defined in the sediment record using Constrained Cluster analysis. The concentrations of metals and Igeo and EF values were low with small variations in Zone I (25.25-12 cm: 1816-1976 AD), indicating that the total input of metals was small. Regarding the anthropogenic source of the total input, only the anthropogenic source of Ni exceeded $20 \%$ (Figure 4), but there was no significant change observed during this period. The anthropogenic contributions of other trace metals were less than $20 \%$ with small variations. The results indicate that the intensity of the human impact was low during this time period because the local population was small, and basic traditional agriculture was the main anthropogenic activity in the watershed during this period [8].

Within Zone II (12-4.25 cm: 1976-2001 AD), no significant change was observed for most of the trace metals, except for an increase of $\mathrm{Zn}$ in the 1980s. However, all the Igeo values of the trace metals 
(Figure 3) were below one, and EF values were below three, indicating that the overall anthropogenic activity was still low. The proportions of the anthropogenic sources of $\mathrm{Cu}, \mathrm{Cr}$, and $\mathrm{Mn}$ were negligible, and that of $\mathrm{Ni}$ was even lower than that in Zone I. However, the anthropogenic contribution of $\mathrm{Zn}$ was much higher than that in Zone I, which may have been caused by the start of the use of chemical fertilizers by local farmers. It has been reported that chemical fertilizers contain significant amounts of $\mathrm{Zn}$ [33]. Similar evidence for an increase in the 1980s was also observed in the $\delta^{15} \mathrm{~N}$, which supports the inference of the use of chemical fertilizers. Although the typical fertilizer $\delta^{15} \mathrm{~N}$ values are relatively low, the $\delta^{15} \mathrm{~N}$ values of agricultural soils tend to be two to three times higher than those of forest soils because of microbial metabolism [34]. The decreased concentrations of the sediment and anthropogenic contributions of $\mathrm{Zn}$ at the end of Zone II may have been due to the reduction of arable land area caused by the ecological restoration that started in $1995 \mathrm{AD}$ in the Lugu Lake Basin [28].

In Zone III (4.25-0 cm: 2001-2010 AD), a remarkable increasing trend was observed in the sedimentary concentrations of the metals $(\mathrm{Cu}, \mathrm{Hg}, \mathrm{Ni}, \mathrm{Cr}, \mathrm{Mn}$, and $\mathrm{Al})$, magnetic susceptibility and the $\delta^{15} \mathrm{~N}$ value, as well as the corresponding Igeo values of the metals. Conversely, concentrations of $\mathrm{Zn}$ and As showed no significant change during this period. A significant increasing trend was also observed in the anthropogenic contributions of $\mathrm{Ni}, \mathrm{Cr}, \mathrm{Mn}$ and $\mathrm{Cu}$ (Figure 4), which supports the suggestion that the anthropogenic input was the main source for the increase of metals. The results demonstrate an increasing trend in the anthropogenic activity in the watershed during this period. Although most of the Igeo and EF values indicate that the current trace metal levels in the sediment are still low, the Igeo values of $\mathrm{Ni}, \mathrm{Mn}$ and $\mathrm{Pb}$ have increased up to one, and $\mathrm{EF}$ values of $\mathrm{Mn}$ and $\mathrm{Ni}$ have increased up to two in recent years, suggesting that there is a risk of environmental deterioration in Lugu Lake caused by the increase in the human impact (Figure 3, Table 1).

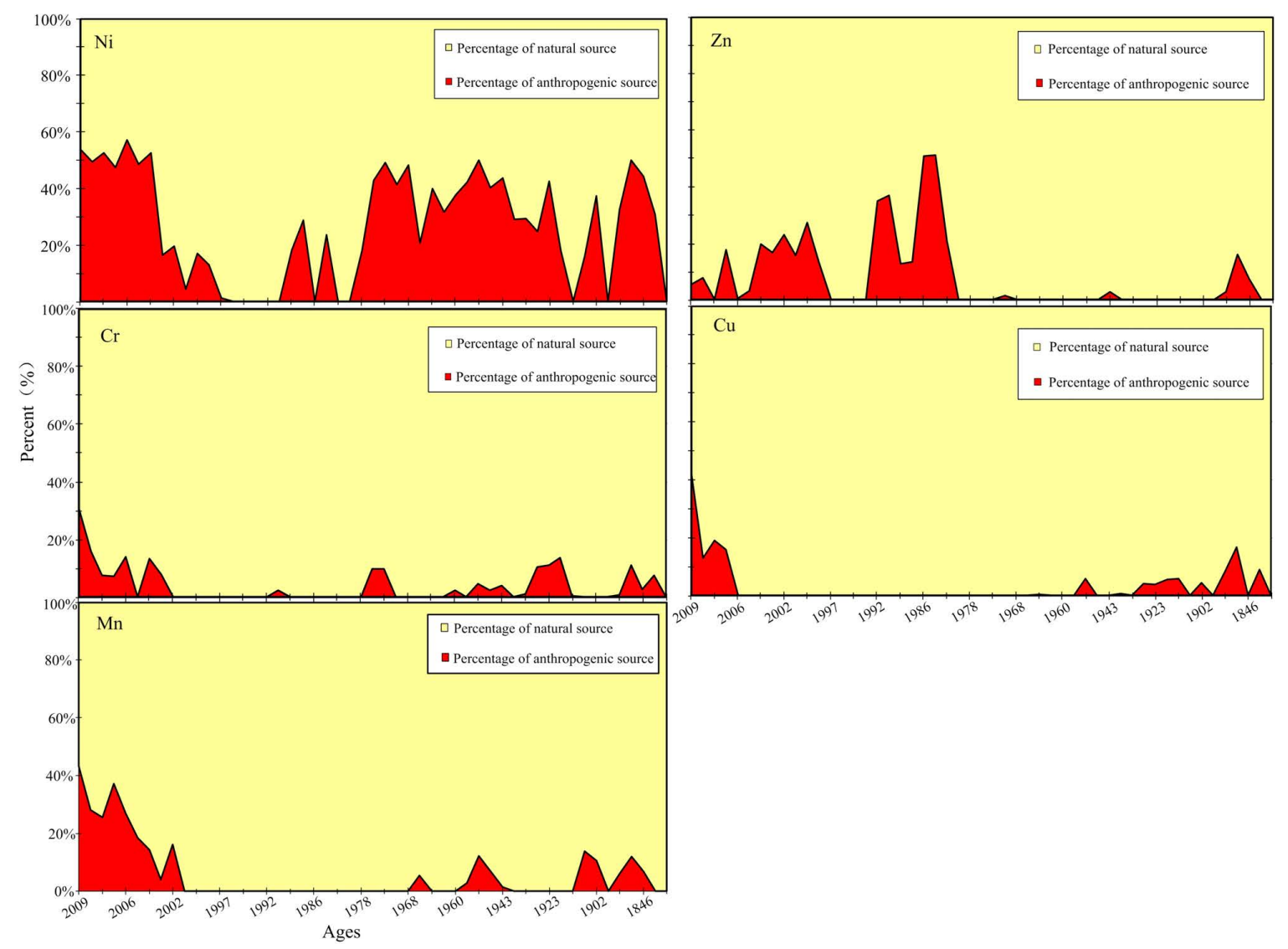

Figure 4. Natural and anthropogenic contributions to the trace metals in Lugu Lake sediment. 
Remote sensing images show that the cultivated land area decreased abruptly by $42.9 \%$, and the forest area increased by 10.6\% from 1995 to 2005, whereas the residential area continued to increase during this time in the Lugu Lake Basin [28]. The rapid development of tourism at Lugu Lake was likely the main anthropogenic activity during this period. It has been reported that the number of tourists increased 45-fold from 1989 to 2005 [28], and continued to increase up to two million visitors per year in 2017 according to the local government. Magnetic susceptibility increased markedly after $2000 \mathrm{AD}$ and was thought to be caused by increasing erosion in Lugu Lake watershed [35], however the decreased farmland area and increased forest area since 1995 AD did not support the increase of erosion in Lugu Lake watershed. The rapid increase in tourism may have caused an increase in waste production and fossil fuel combustion emissions, which resulted in the increase in the input of metals as well as the magnetic susceptibility of sediments [36-38]. The decrease in the anthropogenic fraction of $\mathrm{Zn}$ may be related to the decrease in the cultivated land area [28].

\subsection{Impact of Human Activity on the Changes of Diatom Assemblages in the Sediments}

The sediment diatom record is a well-established proxy that provides information on the long-term changes in an aquatic ecosystem because of the good preservation of silicate shells [39]. The diatom record of Lugu Lake over the past century has been previously analyzed and reported by Chen et al. [4]. To evaluate the anthropogenic activity in the aquatic ecosystem of Lugu Lake over the past century, the sediment diatom record was analyzed according to the three zones defined by the sediment geochemical element record.

In Zone I (1816-1976 AD), no significant change was detected in the sediment diatom assemblage (Appendix Figure A2), which is consistent with the low level of human activity suggested by the metals results during this time period.

In Zone II (1976-2001 AD) a major shift was observed in the diatom assemblages. The relative abundance of Cyclostephanos dubius increased, and eutrophic species Asterionella formosa and Cyclotella ocellata began to appear. The relative abundance of Cyclotella rhomboideo-elliptica decreased abruptly and almost disappeared. Because there was no significant change to the water quality during this time period [16,40,41], Chen et al. [4] studied the impact of climate change on the succession of diatom assemblages. Their RDA results showed that the changes in the diatom assemblages were mainly caused by climate warming during this time period. Climate warming in this region, in particular after the 1990s, increased the length and strength of the thermal stratification in Lugu Lake, which favored small, fast-growing planktonic diatoms such as $C$. ocellata and C. dubius, as well as pennate planktonic $A$. formosa. This resulted in the abrupt decrease in the abundance of the relatively larger size species C. rhomboideo-elliptica in $1983 \mathrm{AD}$ and their disappearance in $1995 \mathrm{AD}$. The trace element results show that the overall anthropogenic contribution during this time period was low, and only the agricultural activity was slightly enhanced, which was reflected by the increase in $\mathrm{Zn}$ and $\delta^{15} \mathrm{~N}$. Because there was no significant change to the water quality of Lugu Lake at this stage, we therefore support the conclusions that the changes in the diatom assemblages were mainly caused by climate warming during this time period [4].

In Zone III (2001-2010 AD) a significant shift of diatom assemblages occurred. The relative abundance of small species C. dubius, C. ocellata and A. formosa, indicators of nutrient-rich conditions, increased significantly, while the oligotrophic and benthic diatoms Pseudostaurosira brevistriata (synonym: Fragilaria brevistriata), Staurosira elliptica (synonym: Fragilaria elliptica) and Staurosirella pinnata (synonym: F. pinnata) decreased during this period. C. dubius is thought to be a typical indicator of eutrophic water [42]. C. ocellata has an extremely wide ecological niche from ultra-oligo- to eutrophic lakes [43]. A. formosa is considered as an indicator of somewhat nutrient-enriched waters [44]. Chen et al. [4] reported that the increases in C. ocellata and A. formosa over the past 10 years may have been related to the elevated levels of nutrients in Lugu Lake. The rapid increase in the trace elements during this time demonstrates the significant increase in human activities in the watershed. The human impact on the lake ecosystem was also confirmed by the deterioration of the lake water quality after 
$2001[41,45]$. Therefore, the pollution resulting from the development of tourism is likely to be the main driving force for the change of diatom assemblages during this time period, which confirms the suggestion of Chen et al. [4] that the changes in the diatom assemblages were mainly driven by nutrient input during this period.

To analyze and verify the influence of the human impact on the changes in the diatom assemblages in Lugu Lake, the relationship between the sediment diatom species with a relative abundance greater than $1 \%$ and the sedimentary trace elements and $\delta^{15} \mathrm{~N}$ that are related to human activities was analyzed using RDA ordination (Figure 5). Monte Carlo permutations and forward selection identified $\mathrm{Mn}, \mathrm{Hg}$, $\mathrm{Cu}, \mathrm{Cr}, \mathrm{Ni}$ and $\delta^{15} \mathrm{~N}$ as significant environmental variables for RDA ordination analysis $(p<0.05, \mathrm{n}=36$; Figure 5). The first two RDA axes were statistically significant, accounting for $46.0 \%$ and $9.9 \%$ of the explained variance, respectively. The nutrient-favoring species A. formosa and C. ocellata were positively correlated with all sedimentary trace metals related to human impact $(r=0.55-0.95, p<0.01, \mathrm{n}=36)$, while the nutrient-favoring species $C$. dubius was only positively correlated with $\operatorname{Mn}(r=0.50, p<0.01$, $\mathrm{n}=36$ ). Oligotrophic species $P$. brevistriata was negatively correlated with all the sedimentary trace metals $(r=-0.4--0.76, p<0.01, \mathrm{n}=36)$. Other benthic diatom species were negatively correlated with most of the metals. The results indicate that the increase in human activities reflected by sediment trace metals benefited the dominance of eutrophic species and was unfavorable to the oligotrophic species. Because the significant increase in trace metals occurred in Zone III, the third stage is the most significant stage of human impact on the succession of diatom assemblages.

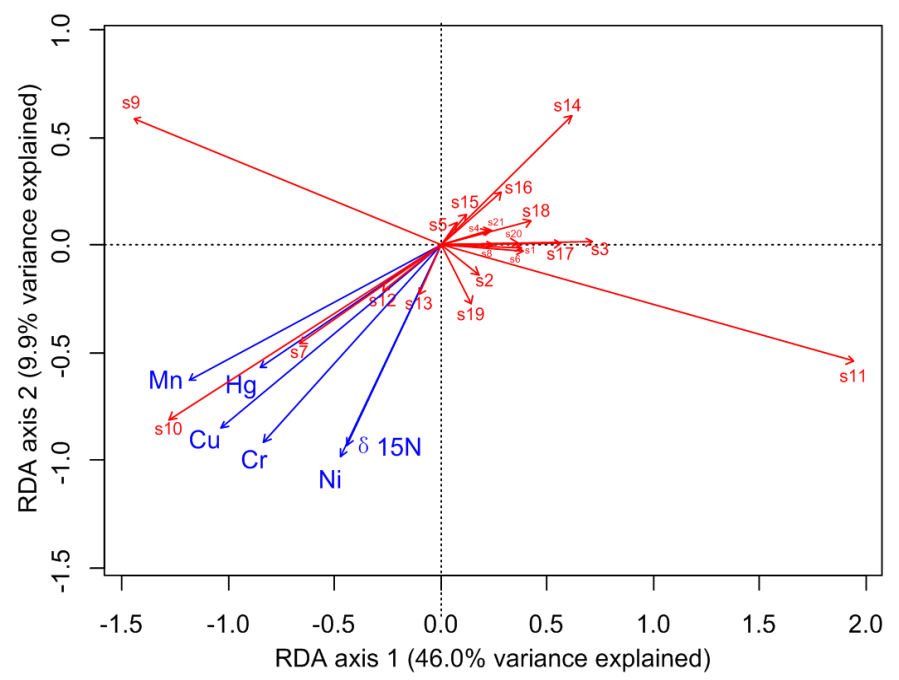

Figure 5. Plot of the redundancy analysis ordination for diatom assemblages (during ca., 1951-2010 AD). The blue arrows represent the significant $(p<0.05)$ environmental variables explaining variation in the diatom assemblages, and the red arrows represent the major diatom species. s1: Achnanthes acares, s2: Achnanthes clevei var. bottnica, s3: Achnanthes grana, s4: Achnanthes lanceolata, s5: Achnanthes levanderi, s6: Amphora pediculus, s7: Asterionella formosa, s8: Cocconeis neothumensis, s9: Cyclostephanos dubius, s10: Cyclotella ocellata, s11: Cyclotella rhomboideo-elliptica, s12: Diploneis elliptica, s13: Epithemia sorex, s14: Pseudostaurosira brevistriata, s15: Staurosira construens $f$. venter, s16: Staurosira elliptica, s17: Pseudostaurosira parasitica, s18: Staurosirella pinnata, s19: Navicula cryptotenella, s20: Navicula subrotundata, s21: Nitzschia frustulum.

To calculate the contributions of human impact and regional climate change to the succession of diatom assemblages in Lugu Lake, the concentrations of trace metals and $\delta^{15} \mathrm{~N}$ in the sediments were used as anthropogenic proxies, and climate change was analyzed based on the average annual rainfall, average annual temperature, and spring, summer, autumn and winter mean temperature data. Forward selection in the minimum adequate models further confirmed that $\mathrm{Mn}, \mathrm{Ni}$, and $\delta^{15} \mathrm{~N}$ (proxies of human impact) and average annual temperature (ATmean) (climate proxy) were the most 
important variables influencing the diatom community composition. The variance partitioning results showed that $\mathrm{Mn}, \mathrm{Ni}, \delta^{15} \mathrm{~N}$ and annual temperature independently explained $24.31 \%, 12.88 \%, 7.09 \%$ and $4.26 \%$ of the changes in diatom assemblages respectively, and $15.01 \%$ of the changes in the diatom assemblages were co-explained by both $\mathrm{Mn}$ and annual temperature (Figure 6). The human impact and climate proxies independently explained $31.59 \%$ and $4.26 \%$ of the change of diatom community respectively, and $18.61 \%$ of the diatom assemblages changes were co-explained by both human impact and climate change when human-induced proxies were combined for analysis. The results indicate that human activities (primarily tourism) are the main driving force for aquatic ecosystem changes in Lugu Lake, in particular after $2000 \mathrm{AD}$ as reflected by the sediment records of the trace metals. Meanwhile, the synergistic effect between human disturbance and climate change cannot be ignored.

In addition to human disturbance and climate changes, other factors that affect the changes in diatom assemblages also cannot be ignored, which were reflected on the residual explanation (45.54\%). Wang et al. [45] reported that low light and stronger thermal stratification conditions are also important for the decrease in benthic diatoms and increase in abundance of plankton. Also, the decrease in small Fragilaria may be due to weaker water column circulation and resuspension of sediment from the littoral to the profundal zone of Lugu Lake. All these factors are included in the unexplained part.

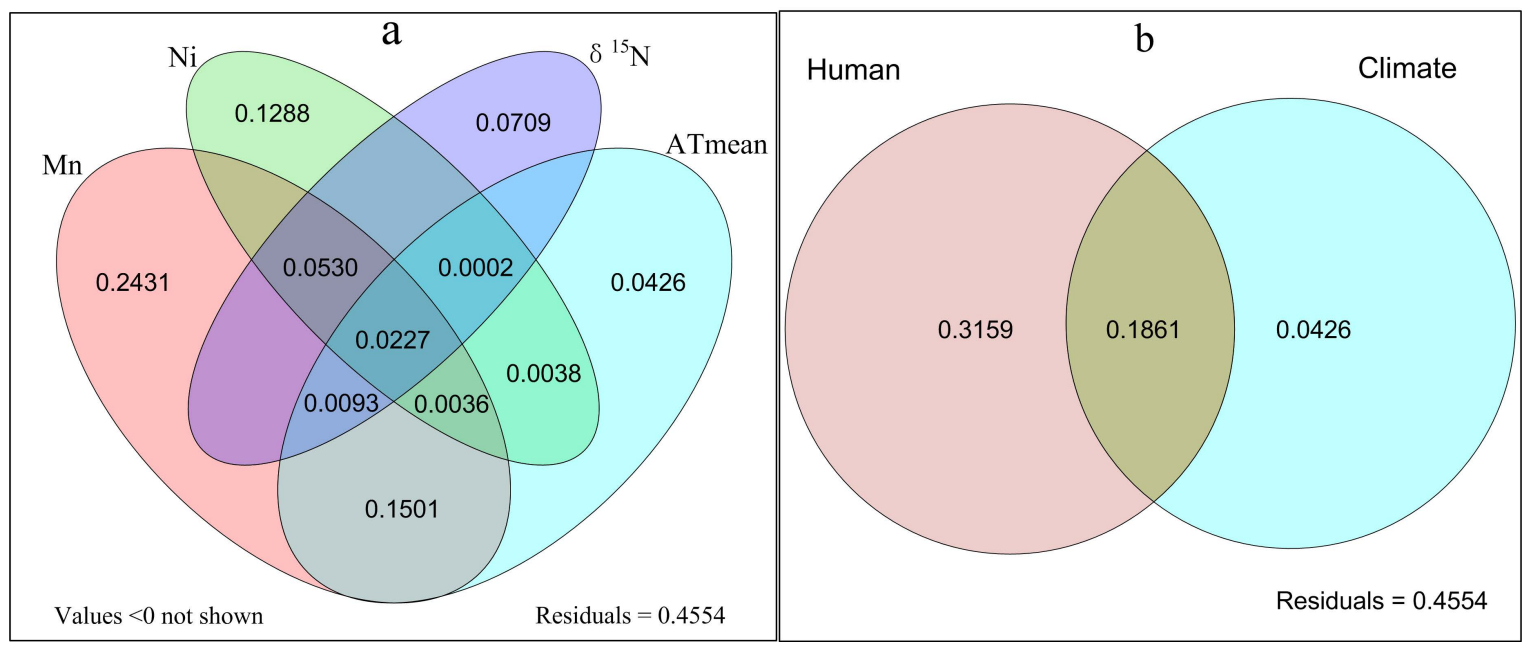

Figure 6. Plot of the variation partitioning analysis for diatom assemblages (during ca., 1951-2010 AD). (a) The four long ellipses from left to right represent effects of $\mathrm{Mn}, \mathrm{Ni}, \delta^{15} \mathrm{~N}$ and annual temperature (ATmean) respectively, and the cross section represents co-influence. Residuals are the unexplained part. (b) The left red circle represents human impact independently, the right green circle represents climate impact independently, and the cross section represents co-influence. Residuals are the unexplained part.

\section{Conclusions}

This research quantitatively assessed the contributions of the local anthropogenic impact and climate change on the change of the diatom communities in Lugu Lake in order to identify the main driving force for the succession of aquatic ecosystems. The human impact and climate proxies independently explained $31.59 \%$ and $4.26 \%$ of the change of diatom community respectively, and the interaction between climate change and human impact accounted for $18.61 \%$ of the change of diatom community. No significant change was observed on the diatom assemblage and minor human activities were detected in Zone I (1816-1976 AD). Climate warming was the main driving force for the shift of diatom assemblage in Zone II (1976-2001 AD), resulting in the increase of relative abundance of small, fast-growing planktonic diatoms and decrease of diatom cell size. Human impact dominated by tourism was the main driving force for the change of diatom community in Zone III (2001-2010 AD), leading to the development of eutrophic species and the reduction of oligotrophic species. The results indicated that the recent low level anthropogenic activities caused greater impact than climate change 
on the diatom community in Lugu Lake. Therefore, the development of human activities, especially tourism, should to be controlled in order to protect the still oligotrophic Lugu Lake.

Author Contributions: Conceptualization, S.Y.; Methodology, Y.L., C.C. and S.Y.; Software, Y.L.; Formal analysis, Y.L.; Investigation, C.C., Y.L.; Writing—original draft, Y.L.; Writing—review \& editing, Y.L., C.C. and S.Y.; Supervision, S.Y.; Project Administration, S.Y.; Funding Acquisition, S.Y.

Funding: This research was funded by the National Science and Technology Major Project for Water Pollution Control and Treatment (Nos. 2013ZX07105-005), the National Natural Science Foundation of China (Nos. 31670464; 41562021).

Acknowledgments: We would like to thank Guangjie Chen, Yuanyuan Liu, Huibin Lu (Yunnan Normal University), Enlou Zhang (Nanjing Institute of Geography and Limnology, CAS) and Hongyu Niu (Central China Normal University) for their help with statistical analysis.

Conflicts of Interest: The authors declare no conflict of interest.

\section{Appendix A}
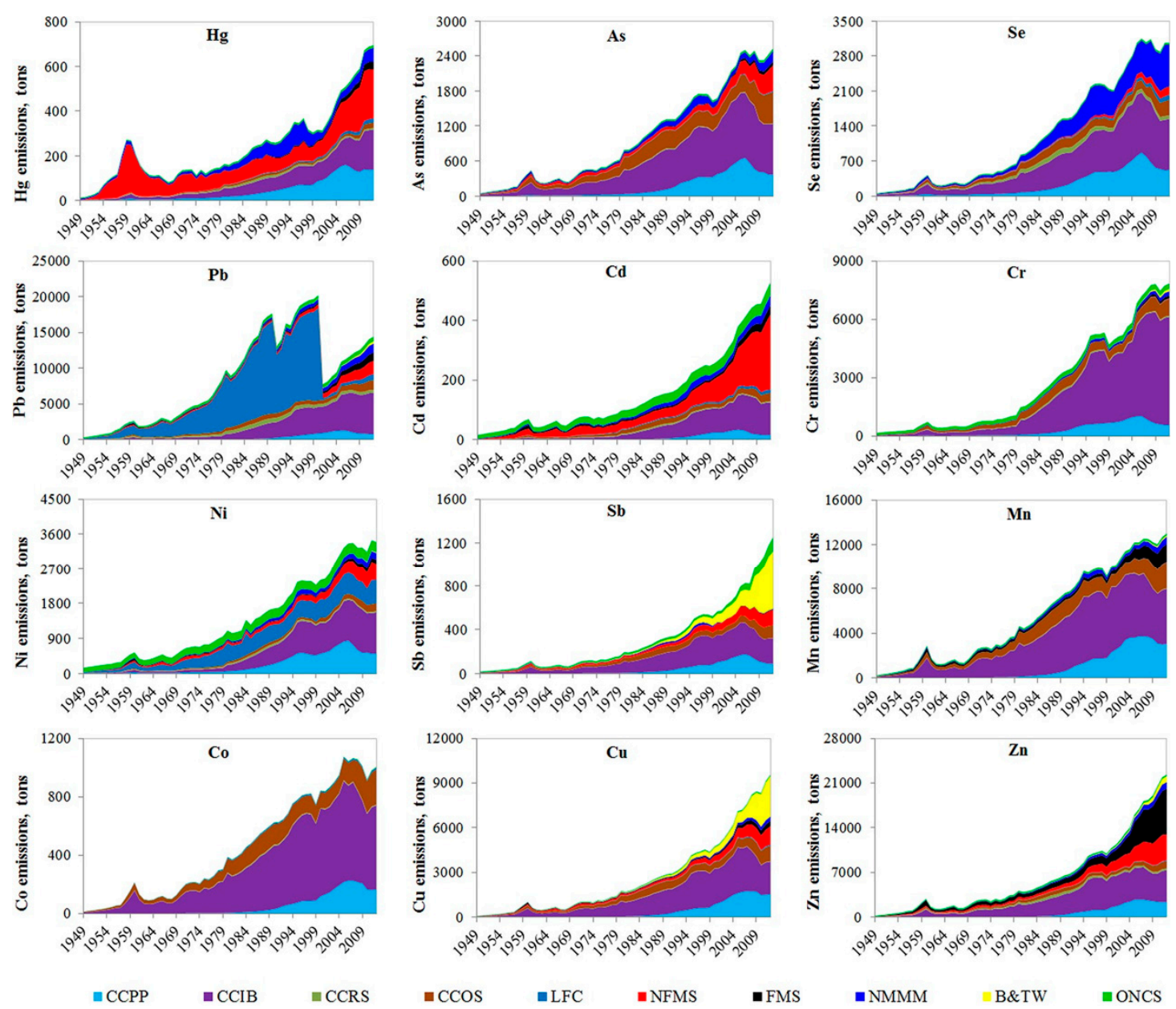

CCPP, coal consumption by power plants; CCIB, coal consumption by industrial boilers; CCRS, coal con- sumption by residential sectors; CCOS, coal consumption by other sectors; LFC, liquid fuels combustion; NFMS, nonferrous metal smelting; FMS, ferrous metal smelting; NMMM, non-metallic minerals manufacturing; B\&TW, brake and tyre wear; ONCS, other non-coal sources (including BB, biomass burning; and MSWI, municipal solid waste incineration)

Figure A1. Historical trends of atmospheric HMs emissions (Tian et al., 2015). 


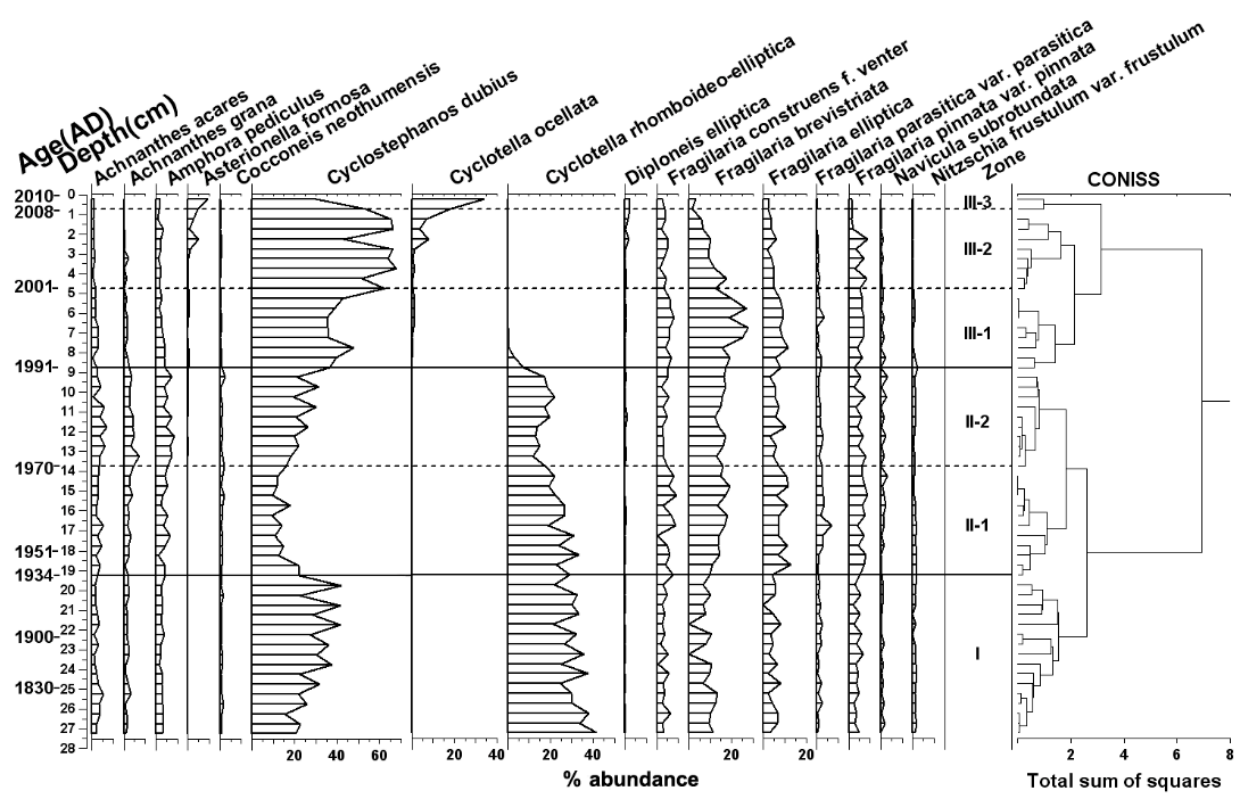

Figure A2. Sedimental diatom succession (Chen et al., 2014).

\section{References}

1. Mcgowan, S.; Barker, P.; Haworth, E.Y.; Leavitt, P.R.; Maberly, S.C.; Pates, J. Humans and climate as drivers of algal community change in Windermere since 1850. Freshw. Biol. 2012, 57, 260-277. [CrossRef]

2. Belle, S.; Verneaux, V.; Millet, L.; Etienne, D.; Lami, A.; Musazzi, S.; Reyss, J.; Magny, M. Climate and human land-use as a driver of Lake Narlay (Eastern France, Jura Mountains) evolution over the last 1200 years: Implication for methane cycle. J. Paleolimnol. 2016, 55, 83-96. [CrossRef]

3. Wu, X.; Liu, S.; Cheng, F.; Hou, X.; Zhang, Y.; Dong, S.; Liu, G. A regional strategy for ecological sustainability: A case study in Southwest China. Sci. Total Environ. 2017, 616, 1224-1234. [CrossRef] [PubMed]

4. Chen, C.H.; Zhao, L.Y.; Zhu, C.; Wang, J.Z.; Jiang, J.H.; Yang, S. Response of diatom community in Lugu Lake (Yunnan-Guizhou Plateau, China) to climate change over the past century. J. Paleolimnol. 2014, 51, 357-373. [CrossRef]

5. Wang, Q.; Yang, X.; Anderson, N.J.; Zhang, E.; Li, Y. Diatom response to climate forcing of a deep, alpine lake (Lugu Hu, Yunnan, SW China) during the Last Glacial Maximum and its implications for understanding regional monsoon variability. Quat. Sci. Rev. 2014, 86, 1-12. [CrossRef]

6. Ma, Z.-F.; Liu, J.; Yang, S.-Q. Climate Change in Southwest China during 1961-2010: Impacts and Adaptation. Adv. Clim. Chang. Res. 2013, 4, 223-229. [CrossRef]

7. Sheng, E.; Yu, K.; Xu, H.; Lan, J.; Liu, B.; Che, S. Late Holocene Indian summer monsoon precipitation history at Lake Lugu, northwestern Yunnan Province, southwestern China. Palaeogeogr. Palaeoclimatol. Palaeoecol. 2015, 438, 24-33. [CrossRef]

8. Zhang, Y.; Su, Y.; Liu, Z.; Chen, X.; Yu, J.; Jin, M. A sediment record of environmental change in and around Lake Lugu, SW China, during the past two centuries. J. Paleolimnol. 2016, 55, 259-271. [CrossRef]

9. Lin, Q.; Liu, E.; Zhang, E.; Nath, B.; Shen, J.; Yuan, H.; Wang, R. Reconstruction of atmospheric trace metals pollution in Southwest China using sediments from a large and deep alpine lake: Historical trends, sources and sediment focusing. Sci. Total Environ. 2018, 613, 331-341. [CrossRef] [PubMed]

10. Li, L.; Yu, Z.; Moeller, R.E.; Bebout, G.E. Complex trajectories of aquatic and terrestrial ecosystem shifts caused by multiple human-induced environmental stresses. Geochim. Cosmochim. Acta 2008, 72, 4338-4351. [CrossRef]

11. Chraibi, V.L.S.; Kireta, A.R.; Reavie, E.D.; Cai, M.; Brown, T.N. A paleolimnological assessment of human impacts on Lake Superior. J. Great Lakes Res. 2014, 40, 886-897. [CrossRef]

12. Laperriere, L.; Fallu, M.; Hausmann, S.; Pienitz, R.; Muir, D. Paleolimnological evidence of mining and demographic impacts on Lac Dauriat, schefferville (subarctic Quebec, Canada). J. Paleolimnol. 2008, 40, 309-324. [CrossRef] 
13. Epp, L.S.; Gussarova, G.; Boessenkool, S.; Olsen, J.; Haile, J.; Schrøder-Nielsen, A.; Ludikova, A.; Hassel, K.; Stenøien, H.K.; Funder, S.; et al. Lake sediment multi-taxon DNA from North Greenland records early post-glacial appearance of vascular plants and accurately tracks environmental changes. Quat. Sci. Rev. 2015, 117, 152-163. [CrossRef]

14. Callender, E.; Rice, K.C. The urban environmental gradient: Anthropogenic influences on the spatial and temporal distributions of lead and zinc in sediments. Environ. Sci. Technol. 2000, 34, 232-238. [CrossRef]

15. Pesce, M.; Critto, A.; Torresan, S.; Giubilato, E.; Santini, M.; Zirino, A.; Ouyang, W.; Marcomini, A. Modelling climate change impacts on nutrients and primary production in coastal waters. Sci. Total Environ. 2018, 628, 919-937. [CrossRef] [PubMed]

16. Wang, S.M.; Dou, H.S. Lakes in China; Science Press: Beijing, China, 1998; p. 580.

17. Bai, X.; Ma, K.; Yang, L.; Zhang, X. Simulating the impacts of land-use changes on non-point source pollution Lugu Lake watershed. Int. J. Sustain. Dev. World Ecol. 2008, 15, 18-27. [CrossRef]

18. Li, K.; Liu, E.; Zhang, E.; Li, Y.; Shen, J.; Liu, X. Historical variations of atmospheric trace metal pollution in Southwest China: Reconstruction from a 150-year lacustrine sediment record in the Erhai Lake. J. Geochem. Exp. 2017, 172, 62-70. [CrossRef]

19. Ati-Hellal, M.E.; Hellal, F.; Dachraoui, M.; Hedhili, A. Plackett-Burman designs in the pretreatment of macroalgae for $\mathrm{Pb}, \mathrm{Cr}$ and Al determination by GF-AAS. C. R. Chim. 2007, 10, 839-849. [CrossRef]

20. Audry, S.; Schäfer, J.; Blanc, G.; Jouanneau, J.M. Fifty-year sedimentary record of heavy metal pollution $(\mathrm{Cd}, \mathrm{Zn}, \mathrm{Cu}, \mathrm{Pb})$ in the Lot River reservoirs (France). Environ. Pollut. 2004, 132, 413-426. [CrossRef]

21. Xu, J.Y.; Chen, Y.W.; Zheng, L.L.; Liu, B.H.; Liu, J.F.; Wang, X.L. Assessment of Heavy Metal Pollution in the Sediment of the Main Tributaries of Dongting Lake, China. Water 2018, 10, 1060. [CrossRef]

22. Han, Y.M.; Jin, Z.D.; Cao, J.J.; Posmentier, E.S.; An, Z.S. Atmospheric $\mathrm{Cu}$ and Pb deposition and transport in lake sediments in a remote mountain area, northern China. Water Air Soil Pollut. 2007, 179, 167-181. [CrossRef]

23. Juggins, S. C2 Version 1.5 User Guide: Software for Ecological and Palaeoecological Data Analysis and Visualisatio; University of Newcastle: Newcastle Upon Tyne, UK, 2007; p. 73.

24. Ter Braak, C.J.F.; Smilauer, P. CANOCO Reference Manual and CanoDraw for Windows User's Guide: Software for Canonical Community Ordination (Version 4.5); Microcomputer Power: New York, NY, USA, 2002; p. 34.

25. Leps, J.; Smilauer, P. Multivariate Analysis of Ecological Data Using CANOCO; Cambridge University Press: Cambridge, UK, 2003; p. 193.

26. Legendre, P.; Legendre, L. Numerical Ecology, 2nd ed.; Elsevier Science: Amsterdam, The Netherlands, 1998; p. 143.

27. The R Core Team. R: A Language and Environment for Statistical Computing; R Foundation for Statistical Computing: Vienna, Austria, 2013; p. 76.

28. Don, R.; Yu, L.; Liu, G. Impact of tourism development on land-cover change in a matriarchal community in the Lugu Lake area. Int. J. Sustain. Dev. World Ecol. 2008, 15, 28-35. [CrossRef]

29. Birch, G.F.; Olmos, M.A. Sediment-bound heavy metals as indicators of human influence and biological risk in coastal water bodies. ICES J. Mar. Sci. 2008, 65, 1407-1413. [CrossRef]

30. Zeng, H.A.; Wu, J.L.; Liu, W. Two-century sedimentary record of heavy metal pollution from Lake Sayram: A deep mountain lake in central Tianshan, China. Quat. Int. 2014, 321, 125-131. [CrossRef]

31. Tian, H.Z.; Zhu, C.Y.; Gao, J.J.; Cheng, K.; Hao, J.M.; Wang, K.; Hua, S.B.; Wang, Y.; Zhou, J.R. Quantitative assessment of atmospheric emissions of toxic heavy metals from anthropogenic sources in China: Historical trend, spatial distribution, uncertainties, and control policies. Atmosp. Chem. Phys. Discuss. 2015, 15, 10127-10147. [CrossRef]

32. Norton, S.A.; Kahl, J.S. Progress in understanding the chemical stratigraphy of metals in lake sediments in relation to acidic precipitation. Hydrobiologia 1991, 214,77-84. [CrossRef]

33. Liu, M.; Li, Y.; Zhang, W.; Wang, Y. Assessment and Spatial Distribution of Zinc Pollution in Agricultural Soils of Chaoyang, China. Procedia Environ. Sci. 2013, 18, 283-289. [CrossRef]

34. Vaalgamaa, S.; Sonninen, E.; Korhola, A.; Weckström, K. Identifying recent sources of organic matter enrichment and eutrophication trends at coastal sites using stable nitrogen and carbon isotope ratios in sediment cores. J. Paleolimnol. 2013, 50, 191-206. [CrossRef] 
35. Zhang, E.L.; Tang, H.Q.; Cao, Y.M.; Langdon, P.; Wang, R.; Yang, X.D.; Shen, J. The effects of soil erosion on chironomid assemblages in Lugu Lake over the past 120 years. Int. Rev. Hydrobiol. 2013, 98, 165-172. [CrossRef]

36. Ozaki, H.; Watanabe, I.; Kuno, K. Investigation of the Heavy Metal Sources in Relation to Automobiles. Water Air Soil Pollut. 2004, 157, 209-223. [CrossRef]

37. Houhou, J.; Lartiges, B.S.; Montargespelletier, E.; Sieliechi, J.; Ghanbaja, J.; Kohler, A. Sources, nature, and fate of heavy metal-bearing particles in the sewer system. Sci. Total Environ. 2009, 407, 6052-6062. [CrossRef]

38. Harikrishnan, N.; Chandrasekaran, A.; Ravisankar, R.; Alagarsamy, R. Statistical assessment to magnetic susceptibility and heavy metal data for characterizing the coastal sediment of East coast of Tamilnadu, India. Appl. Radiat. Isot. 2018, 135, 177-183. [CrossRef]

39. Battarbee, R.W. Diatom analysis. In Handbook of Holocene Palaeoecology; Berglund, B.E., Ed.; John Wiley and Sons: Chichester, UK, 1986; p. 527.

40. Whitmore, T.J.; Brenner, M.; Jiang, Z.; Curtis, J.H.; Moore, A.M.; Engstrom, D.R.; Wu, Y. Water quality and sediment geochemistry in lakes of Yunnan Province, southern China. Environ. Geol. 1997, 32, 45-55. [CrossRef]

41. Wu, G.; Zhang, Q.; Zheng, X.; Mu, L.; Dai, L. Water quality of Lugu Lake: Changes, causes and measurements. Int. J. Sustain. Dev. World Ecol. 2008, 15, 10-17. [CrossRef]

42. Wang, R.; Yang, X.; Langdon, P.; Zhang, E. Limnological responses to warming on the Xizang Plateau, Tibet, over the past 200 years. J. Paleolimnol. 2011, 45, 257-271. [CrossRef]

43. Cremer, H.; Wagner, B. The diatom flora in the ultra-oligotrophic Lake El'gygytgyn, Chukotka. Polar Biol. 2003, 26, 105-114. [CrossRef]

44. Reynolds, C.S. Phytoplankton designer-Or how to predict compositional responses to trophic-state change. Hydrobiologia 2000, 424, 123-132. [CrossRef]

45. Wang, Q.; Yang, X.; Anderson, N.J.; Ji, J. Diatom seasonality and sedimentation in a subtropical alpine lake (Lugu Hu, Yunnan-Sichuan, Southwest China). Antarct. Alp. Res. 2015, 47, 461-472. [CrossRef]

(C) 2019 by the authors. Licensee MDPI, Basel, Switzerland. This article is an open access article distributed under the terms and conditions of the Creative Commons Attribution (CC BY) license (http:/ / creativecommons.org/licenses/by/4.0/). 